\title{
Expression of bacterial genes in transgenic tobacco: methods, applications and future prospects
}

\author{
Sandro Jube \\ Department of Molecular Biosciences and Bioengineering \\ University of Hawaii at Manoa \\ 1955 East-West Road, Ag. Science 218 \\ Honolulu, Hawaii 96822 USA \\ Tel: 8089568210 \\ Fax: 8089563542 \\ E-mail: sandro@ hawaii.edu

\section{Dulal Borthakur} \\ Department of Molecular Biosciences and Bioengineering \\ University of Hawaii at Manoa \\ 1955 East-West Road, Ag. Science 218 \\ Honolulu, Hawaii 96822 USA \\ Tel: 8089566600 \\ Fax: 8089563542 \\ E-mail: dulal@hawaii.edu \\ Websites: http://www.ctahr.hawaii.edu/mbbe/faculty/borthakur.html \\ http://www.ctahr.hawaii.edu/mbbe/
}

Financial support: This work was supported by the USDA-NRICGP Award No. 2002-35107-11659, USDA-TSTAR Award No. 2004-34135-15174 and USDA-TSTAR Award No. 2006-34135-17714.

Keywords: biotechnology, environmental stress, insect/pathogen/herbicide resistance, phytoremediation, transgenics, vaccine production.

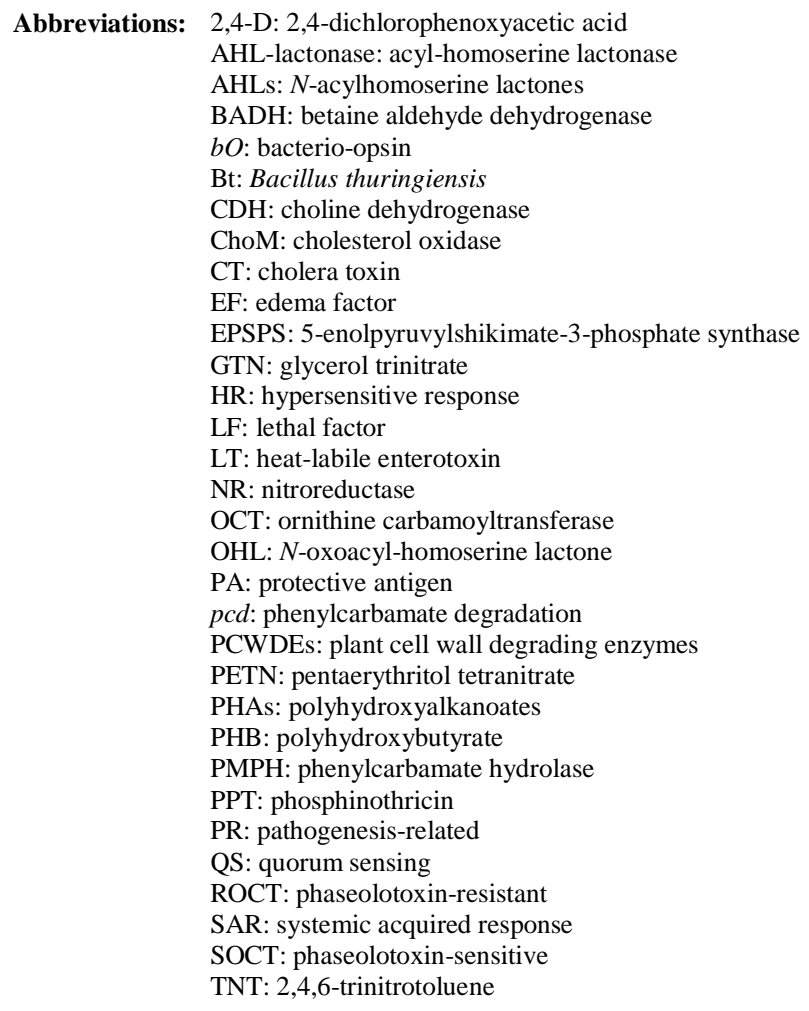

\footnotetext{
*Corresponding author
} 
Jube, S. and Borthakur, D.

UV: ultraviolet

Tobacco is the most commonly used plant for expression of transgenes from a variety of organisms, because it is easily grown and transformed, it provides abundant amounts of fresh tissue and has a well-established cell culture system. Many bacterial proteins involved in the synthesis of commercial products are currently engineered for production in tobacco. Bacterial enzymes synthesized in tobacco can enhance protection against abiotic stresses and diseases, and provide a system to test applied strategies such as phytoremediation. Examples of bacterial gene expression in tobacco include production of antigen proteins from several human bacterial pathogens as vaccines, bacterial proteins for enhancing resistance against insects, pathogens and herbicides, and bacterial enzymes for the production of polymers, sugars, and bioethanol. Further improvements in the expression of recombinant proteins and their recovery from tobacco will enhance production and commercial use of these proteins. This review highlights the dynamic use of tobacco in bacterial protein production by examining the most relevant research in this field.

Tobacco is widely used as a model plant system in transgenic research for several reasons: its molecular genetics is well understood, its genomic mapping is almost complete, genetic transformation can be readily achieved, tobacco plants survive well in vitro and under greenhouse conditions, and tobacco produces large amounts of biomass. Tobacco is also regarded as one of the best systems for chloroplast transformation, which further enhances the effectiveness of tobacco for the expression of recombinant proteins. Tobacco plants can be used as living factories to produce proteins and enzymes, which can be extracted, purified, and used for the manufacturing of pharmaceuticals and other valuable industrial compounds such as biopolymers. Transgenic tobacco plants are also ideal model organisms for the study of basic biological functions, such as plant-pathogen interactions, environmental responses, growth regulation, and senescence.

Tobacco is the most commonly used plant for expression of transgenes from a variety of organisms. Among the many genes from different organisms expressed in tobacco plants, genes of bacterial origin are most common. This review summarizes the most relevant studies using bacterial genes to genetically engineer tobacco for a variety of purposes, including studies on resistance to pathogens, insects, and herbicides; tolerance to abiotic stresses; phytoremediation; production of vaccines; and plant molecular farming (Table $1)$.

\section{PATHOGEN RESISTANCE}

One of the most serious problems in agriculture is the loss of productivity caused by plant pathogens. To cope with the constant threat of invasion by pathogens, plants evolved over time different mechanisms to protect themselves. For a plant to establish a successful self-defense response against pathogens, specific plant receptors need to promptly recognize the pathogenic elicitor molecules. Many bacterial genes involved in pathogenicity have been identified and expressed in transgenic tobacco plants. The genetically transformed plants carrying these genes showed spontaneous activation of different defense mechanisms, leaving the plant in a heightened state of defense. This 'defense mode' greatly enhances the plant's ability to quickly react to a pathogen invasion and more successfully overcome the infection. Among the many economically relevant pathogens afflicting different crops today, Pseudomonas syringae, Phytophthora parasitica, Oidium lycopersicon, and Erwinia carotovora are some of the most devastating pests in agriculture. We will discuss a few genetic engineering strategies that use bacterial genes expressed in tobacco to overcome these pathogens.

\section{Pseudomonas syringae}

Pseudomonas syringae pv. phaseolicola is a seed-borne bacterial pathogen that causes the halo blight disease of common beans (Phaseolus vulgaris). This pathogen produces a phytotoxin, phaseolotoxin, which causes chlorosis in plant tissues. The active component of phaseolotoxin is octicidine, which strongly binds to the enzyme ornithine carbamoyltransferase (OCT), and thereby inhibiting it irreversibly. OCT is a critical enzyme in the urea cycle that converts ornithine and carbamoyl phosphate to citrulline. Inhibition of OCT in plants causes an accumulation of ornithine and a deficiency in arginine, leading to chlorosis and eventual death of the tissue. Virulent strains of $P$. syringae pv. phaseolicola are immune to their own phytotoxin since they possess two different sets of OCT genes, one of which encodes a phaseolotoxinresistant (ROCT) ornithine carbamoyltransferase (Mosqueda et al. 1990). In P. syringae pv. phaseolicola, the $\arg F$ and $\arg K$ genes code for phaseolotoxin-sensitive (SOCT) and ROCT enzymes, respectively. ROCT is orthologous to other SOCT, but it has changes to key conserved amino acids around the carbamoyl phosphate and the ornithine binding sites. The changes in these binding sites decreased the binding affinity of octicidine to ROCT, resulting in a phytotoxin-resistant enzyme (Templeton et al. 2005).

Hatziloukas and Panopoulos (1992) used Agrobacteriummediated transformation to produce tobacco plants carrying the $\arg K$ gene, which encodes ROCT. Since in plant cells OCT is produced in the chloroplast, $\arg K$ was fused to the chloroplast transit sequence of the pea rubisco small subunit $(r b c S)$ gene for localized expression of the enzyme. The ROCT enzyme produced by the transgenic tobacco 
Table 1. Recombinant bacterial proteins expressed in transgenic tobacco.

\begin{tabular}{|c|c|c|c|c|}
\hline Bacterium & Gene & Expressed protein & Function & Reference \\
\hline Pseudomonas syringae & $\operatorname{argK}$ & $\begin{array}{l}\text { ROCT ornithine } \\
\text { carbamoyltransferase }\end{array}$ & $\begin{array}{l}\text { Resistance to Pseudomonas } \\
\text { syringae pv. phaseolicola }\end{array}$ & $\begin{array}{l}\text { Hatziloukas and Panopoulos } \\
\text { (1992) }\end{array}$ \\
\hline Halobacterium halobium & $b O$ & Bacterio-opsin (BO) & $\begin{array}{l}\text { Resistance to Pseudomonas } \\
\text { syringae pv. tabaci }\end{array}$ & Rizhsky and Mittler (2001) \\
\hline Ralstonia solanacearum & popA & PopA & $\begin{array}{l}\text { Resistance to Phytophthora } \\
\text { parasitica var. nicotianae }\end{array}$ & Belbahri et al. (2001) \\
\hline Escherichia coli & entC & Isochorismate isomerase & Salicylic acid production & Verberne et al. (2000) \\
\hline $\begin{array}{l}\text { Pseudomonas } \\
\text { fluorescence }\end{array}$ & pmsB & Pyruvate lyase & Salicylic acid production & Verberne et al. (2000) \\
\hline Erwinia carotovora & $\operatorname{expl}$ & $\begin{array}{l}\text { N-oxoacyl-homoserine lactone } \\
(\mathrm{OHL})\end{array}$ & $\begin{array}{l}\text { Resistance to } \\
\text { Erwinia carotovora }\end{array}$ & Mae et al. (2001) \\
\hline Bacillus sp. $240 B 1$ & aii $A$ & Acyl-homoserine lactonase & $\begin{array}{l}\text { Resistance to } \\
\text { Erwinia carotovora }\end{array}$ & Dong et al. (2001) \\
\hline Bacillus thuringiensis & cry $2 A a$ & Crystal protein (Cry2Aa2) & Insect resistance & Kota et al. (1999) \\
\hline Actinomyces A19249 & choM & ChoM & $\begin{array}{l}\text { Resistance to boll weevil } \\
\text { larvae }\end{array}$ & Corbin et al. (2001) \\
\hline $\begin{array}{l}\text { Agrobacterium } \\
\text { tumefaciens }\end{array}$ & ipt & Cytokinin isopentenyl transferase & $\begin{array}{l}\text { Resistance to tobacco } \\
\text { hornworm }\end{array}$ & Smigocki et al. (1993) \\
\hline $\begin{array}{l}\text { Streptomyces } \\
\text { hygroscopicus }\end{array}$ & bar & PPT acetyltransferase & Bialaphos tolerance & Lutz et al. (2001) \\
\hline Escherichia coli & $\operatorname{aroA}-M 1$ & EPSPS & Glyphosate tolerance & Wang et al. (2003) \\
\hline Arthrobacter oxydans & pcd & PMPH & Phenmedipham tolerance & Streber et al. (1994) \\
\hline Ralstonia eutrophus & $t f d A$ & 2,4-D monooxygenase & 2,4-D tolerance & Lyon et al. (1989) \\
\hline Ochrobactrum anthropi & pqrA & Paraquat resistant protein (PqrA) & Paraquat tolerance & Jo et al. (2004) \\
\hline Escherichia coli & betA & $\mathrm{CDH}$ & Enhance salt tolerance & Holmström et al. (2000) \\
\hline Escherichia coli & betB & $\mathrm{BADH}$ & Enhance salt tolerance & Holmström et al. (2000) \\
\hline Arthrobacter pascens & $\operatorname{cox}$ & Choline oxidase & Enhance salt tolerance & Huang et al. (2000) \\
\hline Erwinia uredovora & crtZ & b-carotene hydroxylase & Enhance UV tolerance & Götz et al. (2002) \\
\hline Synechococcus vulcanus & $\operatorname{des} C$ & Acyl-lipid desaturase & Enhance cold tolerance & Orlova et al. (2003) \\
\hline Escherichia coli & merA & Mercuric ion reductase & Mercury degradation & He et al. (2001) \\
\hline Enterobacter cloacae & $n s f l$ & NR & TNT degradation & Hannink et al. (2001) \\
\hline Enterobacter cloacae & onr & PETN & TNT degradation & French et al. (1999) \\
\hline Bacillus anthracis & pag & PA protein & Anthrax vaccine & Watson et al. (2004) \\
\hline Clostridium tetani & tetC & $\begin{array}{l}\text { Tetanus toxin protein } \mathrm{C} \text { subunit } \\
\text { (TetC) }\end{array}$ & Tetanus vaccine & Tregoning et al. (2003) \\
\hline Escherichia coli & Itb & LT B subunit & Gastroenteritis vaccine & Kang et al. (2003) \\
\hline Escherichia coli & eae & Intimin & E. coli O157:H7 vaccine & Judge et al. (2004) \\
\hline Vibrio cholerae & $c t b$ & CT B subunit & Cholera vaccine & Daniell et al. (2001) \\
\hline Escherichia coli & $m t / D$ & $\begin{array}{l}\text { Mannitol-1-phosphate } \\
\text { dehydrogenase }\end{array}$ & Mannitol production & Tarczynski et al. (1992) \\
\hline Ralstonia eutropha & phbA & $\beta$-ketothiolase & PHB production & Bohmert et al. (2002) \\
\hline $\begin{array}{l}\text { Acidothermus } \\
\text { cellulolyticus }\end{array}$ & e1 & $\begin{array}{l}\text { Cellulase endo-1,4- } \beta-D \text { - } \\
\text { glucanase (E1) }\end{array}$ & Cellulase production & Jin et al. (2003) \\
\hline Bacillus licheniformis & amyl & a-amylase & Alpha-amylase production & Pen et al. (1992) \\
\hline
\end{tabular}

showed greater resistance $(83-100 \%)$ to phaseolotoxin compared to the wild-type OCT (0-22\%). When phaseolotoxin was applied exogenously to the leaves of plants, chlorosis was observed in $100 \%$ of wild-type tobacco, but not seen in the leaves of the transgenic tobacco plants carrying the $\arg K$ gene from $P$. syringae pv. phaseolicola. These observations showed that the insertion of the bacterial $\arg K$ gene in tobacco resulted in the expression of functional ROCT, which provided resistance against $P$. syringae pv. phaseolicola. This technology could be transferred to other commercially important plants to protect them against bacterial halo blight.

In a different approach, Rizhsky and Mittler (2001) used the Halobacterium halobium bacterio-opsin $(b O)$ gene under the control of the wound-inducible promoter Pin2, to develop transgenic tobacco plants resistant to Pseudomonas syringae pv. tabaci via Agrobacterium-mediated 
transformation. Bacterio-opsin activates the self-defense mechanisms in plants by enhancing proton pumping across the cell membrane (Mittler et al. 1995). Transgenic tobacco

plants expressing the $b O$ gene produced hypersensitive response (HR), and showed enhanced expression of different types of defense-related proteins such as chitinase, glucanase, and salicylic acid. Furthermore, there was no spontaneous formation of lesion on transgenic plants, and the expression of the $b O$ gene occurred only after induction by pathogenic infection or wounding. The resulting transgenic tobacco plants expressing the $b O$ gene, when challenged with $P$. syringae pv. tabaci, slowed down the growth of the pathogen compared to wild-type plants. This result indicated that the $b O$ gene expression in tobacco elicits defense responses and enhances resistance to the pathogen.

\section{Phytophthora parasitica}

Belbahri et al. (2001) used the popA gene from the phytopathogenic bacterium Ralstonia solanacearum to develop transgenic tobacco plants resistant to the virulent fungus Phytophthora parasitica var. nicotianae. The elicitor protein PopA from $R$. solanacearum has been shown to be an effective inducer of HRs in tobacco plants (Arlat et al. 1994). Belbahri and colleagues placed the popA gene under the control of the hypersensitivity-related plant promoter hsr203J and transformed tobacco using Agrobacterium. The hrs203J promoter was chosen because it targets the production of the elicitor (PopA) to the infection site, and it is induced both by the pathogen and the PopA protein. Transgenic tobacco plants accumulating the PopA protein showed localized HR and increased resistance to $P$. parasitica. This research demonstrates that expressing effector genes from a bacterial pathogen under the control of an inducible promoter can enhance resistance of plants to fungal pathogens.

\section{Oidium lycopersicon}

Salicylic acid is a naturally occurring plant metabolite that induces pathogenesis-related (PR) proteins and triggers the systemic acquired response (SAR) (Metraux et al. 1990). When salicylic acid induces SAR in plants, it triggers the activation of a family of defense-related genes encoding proteins for resistance against a variety of pathogens. Certain bacteria, such as Escherichia coli and Pseudomonas fluorescence, have well-characterized pathways for the production of salicylic acid. In $E$. coli, the entC gene encodes the enzyme isochorismate isomerase, which converts chorismic acid to salicylic acid. While in $P$. fluorescence, the $p m s B$ gene encodes pyruvate lyase, which converts isochorismic acid into salicylic acid. Verberne et al. (2000) developed transgenic tobacco plants that constitutively expressed both entC and $p m s B$ in the chloroplast. Transformation was accomplished through biolistic methods. The transgenic tobacco plants expressing these bacterial genes showed accumulation of salicylic acid that were up to 1000 times higher than in wild-type tobacco. When challenged with the fungus Oidium lycopersicon, the transgenic tobacco plants showed increased levels of resistance compared to the wild-type plants. The transgenic plants did not show any adverse effects due to the high level expression of salicylic acid. Since the role of salicylic acid in triggering SAR against a variety of pathogens is believed to be similar for all higher plants, the same strategy used in this research can be applied to other commercially important crops to enhance their resistance to different pathogens.

\section{Erwinia carotovora}

The soil-borne Gram-negative bacterium Erwinia carotovora causes the soft rot disease on a variety of commercially important fruits and vegetables, including carrot, cucumber, potato, lettuce, tomato, and onion. This disease is caused mainly through the action of extracellular plant cell wall degrading enzymes (PCWDEs). The expression of these enzymes in E. carotovora is activated by the signaling molecule $N$-oxoacyl-homoserine lactone (OHL). OHL, a bacterial pheromone, is a member of the $\mathrm{N}$ acylhomoserine lactones (AHLs) family, which controls quorum sensing (QS) (Pirhonen et al. 1993). QS in E. carotovora regulates, in a cell density-dependent manner, the expression of virulence factors such as PCWDE, hrp secretion system, and carbapenem antibiotic production (von Bodman et al. 2003). Mae et al. (2001) suggested that the expression of the QS signaling molecule OHL in plants would offer them an immunity boost against E. carotovora, by triggering PCWDEs synthesis even at the early onset of invasion when pathogen cell density is low. Using Agrobacterium-mediated transformation, the researchers developed tobacco plants carrying the E. carotovora gene expI, which is responsible for OHL biosynthesis. These transgenic plants produced OHL up to $1 \mu \mathrm{g} / \mathrm{g}$ of fresh weight. To test whether this level of expression of recombinant $\mathrm{OHL}$ in the transgenic plants could trigger PCWDEs synthesis, the researchers inoculated plants with a non-virulent expI-mutant strain of E. carotovora that lost the ability to synthesize PCWDEs. The expI mutants were able to grow on OHL-synthesizing transgenic tobacco but not on control plants. Wild-type plants inoculated with virulent $E$. carotovora were two times more susceptible to the soft rot disease compared to the transgenic plants expressing OHL.

A different approach to curb E. carotovora infection was taken by Dong et al. (2001). Instead of expressing in plants genes that encode QS signaling molecules, the researchers expressed bacterial genes that disrupt QS signaling, and would therefore decrease pathogen virulence. The researchers transformed tobacco plants with the aiiA gene from Bacillus sp. 240B1, which encodes acyl-homoserine 
lactonase (AHL-lactonase). AHL-lactonase renders $\mathrm{N}$ acylhomoserine lactones (AHLs) inactive by hydrolyzing their lactone bonds. Once AHLs are inactivated, QS can no longer be controlled. Transgenic tobacco plants producing AHL-lactonase showed increased resistance to $E$. carotovora infection. This resistance may be due to the plant's ability to interrupt bacterial QS signaling by degrading AHL molecules, which in turn negatively affects E. carotovora pathogenesis.

\section{INSECT RESISTANCE}

Insect infestation causes major agricultural losses worldwide. For many years, the most successful means of insect eradication has been through the use of chemical insecticides. An alternative to chemical insecticides is the use of transgenic plants carrying bacterial genes that encode proteins toxic to insects. As an example, transgenic plants expressing the cry genes from the soil bacterium Bacillus thuringiensis $(\mathrm{Bt})$ has become the most prevalent method of insect control for several commercial crops. Besides the cry genes from $B$. thuringiensis, other bacterial genes such as choM and ipt from Actinomyces and Agrobacterium, respectively, have strong insecticidal properties and have been transformed into tobacco plants in order to determine their ability to control insect infestation.

\section{Bt cry2Aa gene}

Transgenic plants expressing insecticidal crystal protein genes (cryA, crylA, cry2A, etc.) from Bt are known as Bttransgenic plants. Most commercial Bt-transgenic crops carry a single cry gene, inserted into the chromosome, that expresses the Bt protein constitutively and usually at low levels. Kota et al. (1999) developed, via biolistic transformation, chloroplast-targeted transgenic tobacco plants, in which the B. thuringiensis Cry2Aa2 protein was overexpressed. In the transgenic tobacco plants carrying cry $2 \mathrm{Aa} 2$ in the plastome, $3 \%$ of total soluble protein was Cry2Aa2, which is 30-fold higher than Cry protein expression levels in commercial Bt crops containing cry genes in the chromosome. During insect bioassay studies, $100 \%$ mortality was achieved when transgenic tobacco leaves were fed to Cry1A-resistant tobacco budworm, cotton bollworm, and beet armyworm insects. These data suggest that chloroplast-targeted expression of a Bt protein can result in higher levels of resistance to insect pests, enhancing the effectiveness of commercial Bt-crops.

\section{Actinomyces A19249 choM gene}

Cotton boll weevil larvae, which feeds inside young fruits (bolls) is one of the most damaging cotton pests in the United States. The choM gene, isolated from Actinomyces A19249, encodes the enzyme cholesterol oxidase (ChoM), which has powerful insecticidal properties against the boll weevil larvae (Corbin et al. 1994). This enzyme acts by oxidizing cholesterol in the insect's midgut epithelial membrane, disrupting the physical and functional properties of the membrane and causing death. Corbin et al. (2001) developed transgenic tobacco plants expressing the Actinomyces choM gene. The transgenic tobacco plants were produced through Agrobacterium-mediated transformation. The researchers observed that the mortality rate of cotton boll weevil larva feeding on these transgenic plants ranged from $54 \%$ to $87 \%$. These data indicate that expression of bacterial ChoM in the tissues of transgenic plants can result in an effective and environmentally safe eradication method against cotton boll weevil.

\section{Agrobacterium tumefaciens ipt gene}

Tobacco hornworm (caterpillars of Manduca sexta) is one of the most destructive insect pests of tobacco plants. The transfer of the Agrobacterium ipt gene, encoding cytokinin isopentenyl transferase, to transgenic plants has been shown to increase the levels of endogenous cytokinin and effectively enhance the resistance of plants to a number of insects. Smigocki et al. (1993) introduced the ipt gene into tobacco plants by Agrobacterium-mediated transformation. The transgene was placed under the control of a woundinducible promoter from the potato proteinase inhibitor II (PI-IIK) gene. Transgenic tobacco plants had a 25- to 35fold increase in ipt mRNA following induction by wounding of the plant tissue. Exogenous application of the transgenic leaf crude extracts reduced the hatch rate of hornworm eggs by $30 \%$. In insect feeding assays, hornworm larvae consumed up to $70 \%$ less leaf material from the transgenic tobacco plants compared to wild-type plants. These studies illustrate the importance of continued identification of bacterial genes that have insecticidal properties for the control of agricultural insects in a more efficient and environmentally safe manner.

\section{HERBICIDE RESISTANCE}

Broad-spectrum herbicides kill weeds as well as crop plants; therefore, development of herbicide-resistant plants is important for an effective weed management program. As the metabolic pathways involved in herbicide degradation are characterized in a variety of bacteria, many new genes have been identified and cloned. We will discuss here a few examples of bacterial genes involved in herbicide degradation and their use in transgenic tobacco plants to enhance resistance against the herbicides bialaphos, glyphosate, phenmedipham, 2,4-D (2,4dichlorophenoxyacetic acid), and Paraquat.

\section{Bialaphos}

Phosphinothricin (PPT) is the active ingredient in the non selective herbicide bialaphos. The mode of action of PPT is through the inhibition of the enzyme glutamine synthetase, which is required for ammonia assimilation in plants (Wild and Wendler, 1991). The bacteria Streptomyces hygroscopicus contain the bar gene encoding the enzyme PPT acetyltransferase, which is responsible for the detoxification of PPT into an inactive form (Thompson et al. 1987). Lutz et al. (2001) used biolistic transformation to 
develop tobacco plants carrying the bar gene in their plastid genome. Conversion of PPT into inactive PPT was observed in the transgenic plants treated with bialaphos, but not in wild-type tobacco plants. Callus tissue from transformed plants were resistant up to $100 \mathrm{mg} / \mathrm{L}$ PPT, while leaf sections from the wild-type plants grown at 4 $\mathrm{mg} / \mathrm{L}$ PPT showed chlorosis and did not form callus. Following herbicide application, the transgenic plants remained healthy but the wild-type plants died within two weeks. This research shows that it is possible to develop bialaphos-resistant transgenic plants by expressing a bacterial gene for PPT detoxification.

\section{Glyphosate}

Glyphosate, the active ingredientof the widely used weed control agent Roundup, is a major broad-spectrum herbicide used in agriculture. Glyphosate kills weedsby inhibiting the enzyme 5-enolpyruvylshikimate-3-phosphate synthase (EPSPS), which is a key enzyme in the shikimate pathway and is necessary for the synthesis of aromatic amino acids (Zhou et al. 2003). Scientists isolated and characterized a gene, aroA-M1 from $E$. coli, which encodes a glyphosate-resistant EPSPS (He et al. 2001). A tobacco chloroplast transit peptide sequence was added to the 5' end of the aroA-M1 gene for chloroplast-specific expression. The resulting construct was cloned behind the CaMV 35S promoter and transferred into tobacco by Agrobacteriummediated transformation (Wang et al. 2003). The transgenic tobacco plants were two times more tolerant to glyphosate compared to wild-type tobacco plants.

\section{Phenmedipham}

The herbicide phenmedipham is commercially used as a post-emergence herbicide mainly in the production of sugar beet and strawberries. Researchers isolated the phenylcarbamate degradation ( $p c d)$ gene from the bacterium Arthrobacter oxydans strain P52. The pcd gene encodes the enzyme phenylcarbamate hydrolase (PMPH), which detoxifies phenmedipham through hydrolytic cleavage of the carbamate bond between the benzene rings (Pohlenz et al. 1992). The A. oxidans pcd-coding sequence was fused with a CaMV $35 \mathrm{~S}$ promoter and introduced into tobacco plants by Agrobacterium-mediated gene transfer (Streber et al. 1994). Transgenic and wild-type tobacco plants were sprayed with phenmedipham doses corresponding to field application rates of $1 \mathrm{~kg} / \mathrm{ha}, 3 \mathrm{~kg} / \mathrm{ha}$, and $10 \mathrm{~kg} / \mathrm{ha}$. Whereas $1 \mathrm{~kg} / \mathrm{ha}$ is completely lethal for wild-type plants, transgenic plants expressing high levels of PMPH showed resistance to application rates up to 10 $\mathrm{kg} / \mathrm{ha}$.

\section{2,4-D}

The chlorinated phenoxy compound 2,4-D is an auxin analog and is commercially used as a herbicide for the control of broad leaf weeds. 2,4-D acts by over-stimulating plant metabolism and increasing the synthesis of proteins that negatively affect respiration, cell division and many other enzymatic activities in the cell. The $t f d A$ genefrom the Gram-negative bacterium Ralstonia eutrophus strain JMP134 encodes the enzyme 2,4-D monooxygenase, involved in the conversion of 2,4-D to the non-active enzyme 3-oxoadipate (Streber et al. 1987). Lyon et al. (1989) cloned the gene $t f d A$ behind a CaMV 35S promoter in a binary vector and introduced it into tobacco plants by Agrobacterium-mediated transformation. Through leaf discs and seed germination assays, the researchers verified that $t f d A$ transgenic tobacco plants expressing 2,4-D monooxygenase showed increased tolerance to exogenous application of 2,4-D compared to wild-type plants. Moreover, the transgenic seedlings could tolerate up to eight times the amount of herbicide used for control of weeds in the field. These data demonstrated that expressing the bacterial 2,4-D monooxygenase gene could develop herbicide-resistant transgenic crop plants.

\section{Paraquat}

Paraquat, also called methyl viologen, is a non-selective herbicide, which destroys green plant tissues on contact by generating superoxides and other radicals that disrupt plant cells membranes. Researchers isolated the Paraquatresistance pqrA gene from the bacterium Ochrobactrum anthropi strain JW2 (Won et al. 2001). Jo et al. (2004) used Agrobacterium-mediated transformation to develop transgenic tobacco plants expressing the pqrA gene. The resulting transgenic plants displayed higher resistance against paraquat than the wild-type plants. The transformed tobacco plants also showed lower levels of paraquat accumulation in their tissues compared to untransformed tobacco, establishing that the bacterial protein PqrA is effective in the detoxification of paraquat.

\section{IMPROVED TOLERANCE TO ABIOTIC STRESSES}

Many bacterial genes involved in different environmental stresses have been identified. The expression of certain bacterial stress-related proteins in plants may directly or indirectly protect plants against specific environmental stresses such as high salinity, high UV radiation, drought, and low temperature. As the role of these bacterial genes in stress adaptation becomes known, new strategies can be devised to improve stress tolerance in crops.

\section{Salt tolerance}

Close to $40 \%$ of all arable lands cannot be used because of potential salinity problems. Therefore, the development of transgenic plants tolerant to high salinity is essential for increasing food production worldwide. Plants naturally produce organic compounds of low molecular weight, called 'compatible solutes', that enhance the plant's 
tolerance to salt. One of the most effective compatible solutes is betaine, which is not produced or accumulated in several important crop plants. Betaine helps plants cope with a saline environment by regulating the osmotic potential in the cell cytoplasm and protecting proteins from degradation (Robinson and Jones, 1986). In all betaine producers, its biosynthesis is accomplished in a two-step process. In the first step, which involves the oxidation of choline to the intermediate betaine aldehyde, different enzymes catalyse the reaction depending on the organism. For example, in E. coli this step is catalyzed by choline dehydrogenase $(\mathrm{CDH})$, followed by conversion of betaine aldehyde into betaine by the enzyme betaine aldehyde dehydrogenase (BADH) (Landfald and Strom, 1986). Holmström et al. (2000) used Agrobacterium-mediated transformation to introduce the $E$. coli bet $A$ and $\operatorname{bet} B$ genes into tobacco plants, which do not naturally accumulate betaine. The $E$. coli bet $A$ encodes $\mathrm{CDH}$ while bet $B$ encodes BADH. Transgenic tobacco plants producing both $\mathrm{CDH}$ and BADH were developed by crossing betA- and betBproducing plants and selecting for double transgenic lines. Transgenic tobacco expressing both betA and betB produced a considerable amount of betaine $(66 \pm 18 \mathrm{nmol} / \mathrm{g}$ of fresh weight) and were able to grow in the presence of $200 \mathrm{mM} \mathrm{NaCl}$.

In a different approach, Huang et al. (2000) transformed tobacco plants with the cox gene, encoding choline oxidase from Arthrobacter pascens, and obtained transgenic plants that accumulated betaine up to $13 \mu \mathrm{mol} / \mathrm{g}$ of dry weight. However, when the same transgenic lines were grown in the presence of exogenous choline $(20 \mathrm{mM})$, betaine synthesis increased up to $80 \mu \mathrm{mol} / \mathrm{g}$ of dry weight. No increase in betaine content was observed in the wild-type plants supplemented with choline. Thus, the A. pascens cox gene can catalyze both steps of betaine biosynthesis from choline more efficiently than the $E$. coli $\mathrm{CDH}$ and $\mathrm{BADH}$ in transgenic tobacco.

\section{UV tolerance}

In the tropics, plants are often exposed to excess light intensity and ultraviolet (UV) radiation that can be harmful if the stress surpasses the plant's capacity for defense and repair. UV radiation causes photooxidative stress in all cellular compartments (Jansen et al. 1998). In bacteria, fungi, and photosynthetic organisms, carotenoids are naturally occurring pigments that have a major function in photoprotection. Carotenoids protect organisms from excess UV radiation by dispersing excess light energy and quenching free radicals (Niyogi, 1999). In plants, carotenoid biosynthesis starts with the formation of phytoene from two molecules of geranylgeranyl pyrophosphate (GGPP). Phytoene is then subjected to four consecutive desaturation reactions that result in the formation of lycopene. Through the action of cyclase enzymes, lycopene is converted to $\beta$-carotene, which serves both as an end product and as the main precursor for many other carotenoids including the xanthophylls. Zeaxanthin is a well-studied carotenoid of the xanthophyll family that is formed by the hydroxylation of $\beta$-carotene.

Götz et al. (2002) used Agrobacterium-mediated gene transfer to produce tobacco plants that carry a heterologous carotenoid gene encoding the enzyme $\beta$-carotene hydroxylase $(\operatorname{crt} Z)$ isolated from the bacterium Erwinia uredovora. $\beta$-carotene hydroxylase is directly involved in the formation of zeaxanthin from the precursor $\beta$-carotene. The $c r t Z$ gene was fused to the transit peptide of rubisco small subunit, placed under the control of the constitutive 35S CaMV promoter and transferred into tobacco. Zeaxanthin accumulation in the transgenic plants expressing $\beta$-carotene hydroxylase was two-fold compared to the wild-type plants. Under UV stress, these plants maintained a higher biomass and greater amount of photosynthetic pigments than wild-type plants exposed to UV radiation. These results indicate that increased zeaxanthin biosynthesis in transgenic tobacco plants protects plants from UV damage.

\section{Low temperature}

The main effect of low temperature exposure in plants is a decrease in the fluidity of biological membranes resulting in photosynthesis inhibition (Murata and Los, 1997). Plant cells acclimate to cold through the synthesis of unsaturated fatty acids that cause the lipid bilayer of cell membranes to become more fluid, preventing the lipids from phase separation (Nishida and Murata, 1996). Fatty acid desaturases are the enzymes responsible for introducing double bonds into fatty acids, enhancing the molecular motions of lipids at low temperatures (Los and Murata, 1998). In higher plants, there are two major types of fatty acid desaturases: acyl-ACP desaturases and acyl-lipid desaturases. Orlova et al. (2003) introduced into tobacco plants the gene for acyl-lipid desaturase $(\operatorname{des} C)$ from the thermophilic cyanobacterium Synechococcus vulcanus, through Agrobacterium-mediated transformation. The enzymatic activity of the desaturase was investigated by comparing the fatty acid composition in leaves of transgenic and wild-type tobacco plants. Transgenic plants expressing desC showed significant alterations in cell membrane lipids, resulting in a four-fold increase in the total amount of unsaturated fatty acids compared to untransformed tobacco plants. The cold tolerance of the transgenic plants was tested by measuring the amount of electrolytes that leaked into water extracts from plant tissues damaged by low temperatures as a percent of electrolytes leaked after complete destruction of the tissues by boiling. The amount of electrolytes, which gave an estimation of the index of injury to the tissue, was determined by the electric conductivity of the water extracts. Based on this assay, the transgenic tobacco plants were found to be about twice more resistant to cold at $0^{\circ} \mathrm{C}$, compared to wild-type plants. This study indicates that the 
increased amount of polyunsaturated fatty acids in the membrane lipids of transgenic plants expressing the bacterial enzyme acyl-lipid desaturase can result in higher tolerance of plants to cold temperatures, which may translate to an increase in crop productivity.

\section{PHYTOREMEDIATION}

Phytoremediation is the process of detoxifying contaminated soils through the use of plants. Some plants have the natural capacity to extract pollutant materials from the soil and degrade them into less toxic components. To enhance the plant natural remediation capabilities, scientists have developed transgenic plants that carry bacterial genes for detoxification of certain inorganic pollutants, such as mercury and 2,4,6-Trinitrotoluene (TNT).

\section{Mercury phytodetoxification}

Mercury pollution is caused mainly by the organomercurial waste generated through agricultural, mining, and industrial activities. Some mercury-resistant Gram-negative bacteria can detoxify organomercurial compounds from the environment, by converting methylmercury into $\mathrm{Hg}^{2+}$; then further degrading $\mathrm{Hg}^{2+}$ into metallic mercury $\left(\mathrm{Hg}^{0}\right)$, which is the least toxic form of mercury (Summers, 1986). Genes encoding mercury detoxification have been isolated from these bacteria. The mer $B$ gene encodes the enzyme organomercurial lyase that catalyzes the breakdown of the carbon-mercury bond in methylmercury, producing $\mathrm{Hg}^{2+}$, whilethe merA gene encodes the enzyme mercuric ion reductase for reduction of $\mathrm{Hg}^{2+}$ to $\mathrm{Hg}^{0}$ (Summers, 1986). Through Agrobacterium-mediated transformation, He et al. (2001) generated transgenic tobacco plants carrying the $E$. coli merA gene. Transformed tobacco plants expressing mercuric ion reductase were resistant to $\mathrm{HgCl}_{2}$ concentrations up to $350 \mu \mathrm{M}$, while the untransformed plants could not survive in $\mathrm{HgCl}_{2}$ concentration of just 50 $\mu \mathrm{M}$. Although merA conferred some level of resistance to mercury in these plants, $\operatorname{mer} B$ expression is also required in the transgenic plants in order to achieve higher levels of mercury detoxification.

\section{Phytodegradation of explosives}

TNT is one of the most toxic explosives known to man, affecting plants, animals and most microorganisms. Enterobacter cloacae PB2, a Gram-negative bacterium, is able to utilize TNT as a sole source of nitrogen (Binks et al. 1996). The $n s f l$ gene, isolated from E. cloacae, encodes the enzyme nitroreductase (NR), which is responsible for the reduction of the nitro groups of TNT, producing hydroxylamino- and amino-dinitrotoluenes (French et al. 1998). Hannink et al. (2001) transferred the bacterial $n s f l$ gene into tobacco via Agrobacterium-mediated gene transformation. Transgenic tobacco plants expressing the bacterial NR enzyme tolerated TNT concentrations up to
$0.5 \mathrm{mM}$, which is the solubility limit of TNT in aqueous solution.

In a different study, tobacco plants were transformed with the E. cloacae onr gene, which encodes the enzyme pentaerythritol tetranitrate (PETN) reductase (French et al. 1999). PETN reductase reduces PETN and glycerol trinitrate (GTN) to nitrite. Seeds from transgenic tobacco plants carrying the onr gene germinated and grew in media containing $1 \mathrm{mM}$ GTN, which was toxic to untransformed seeds. The researchers showed that transgenic tobacco plants expressing microbial NR and PETN reductase could not only tolerate high amounts of TNT, GTN, and PETN but also uptake and degrade them, making phytodetoxification a possibility in the cleanup of fields contaminated with nitroaromatic and nitrate ester explosives.

\section{VACCINE PRODUCTION}

The production of vaccines in plants has many advantages over other more traditional methods of manufacturing and distribution. Plant-based vaccines are less expensive to produce and their administration is safer and simpler since they do not require trained personnel. To this date, most research done with plant-based vaccines have focused on diseases caused by viral infections, such as hepatitis, AIDS, herpes, rabies, foot and mouth disease, and diarrhea. In this section, we discuss recent reports on the expression of proteins from bacterial pathogens in tobacco plants. So far, antigen proteins from several human pathogens including Bacillus anthracis, Clostridium tetani, Escherichia coli, and Vibrio cholerae have been expressed in tobacco as candidate vaccines.

\section{Bacillus anthracis}

Bacillus anthracis is a Gram-positive soil-borne bacterium that causes the anthrax disease, which afflicts herbivores and humans. The main virulence factor of $B$. anthracis is an exotoxin protein composed of three components: protective antigen (PA), lethal factor (LF) and edema factor (EF). The only anthrax vaccine licensed for human use in the U.S. is made from a cell-free filtrate that contains a mix of cellular products including $\mathrm{PA}, \mathrm{LF}$ and $\mathrm{EF}$, and it is not considered safe due to a high rate of side effects (Pittman, 2002). Watson et al. (2004) cloned the PA gene (pag) into a chloroplast vector, designated pLD-JW1, and through the use of biolistic method of transformation, introduced pag into the chloroplast of tobacco. The resultant transgenic plants produced a maximum PA of $18.1 \%$ of the total soluble protein and the extracted PA was functionally active. Since current anthrax vaccine production methods are not efficient, transgenic plants expressing high levels of Pas may offer an effective and inexpensive way to produce anthrax vaccine in large scale. 


\section{Clostridium tetani}

Clostridium tetani is the bacterium responsible for causing the disease tetanus, which globally kills 300,000 newborns and 30,000 birth mothers every year (Pascual et al. 2003). After infection, $C$. tetani produces a strong toxin called tetanospasmin, which contains two subunits: $\mathrm{H}$ and $\mathrm{L}$. The $\mathrm{H}$ subunit has three functional domains (zinc-binding motif 'ZBD', $\mathrm{H}_{\mathrm{N}}$, and $\mathrm{H}_{\mathrm{C}}$ ). The $\mathrm{H}_{\mathrm{C}}$ functional domain, also known as TetC fragment, has been widely used as a candidate subunit vaccine since it is non-toxic and it causes both mucosal and systemic immune response. Tregoning et al. (2003) developed transplastomic tobacco plants expressing the tetanus toxin protein TetC in the chloroplast. The tet $C$ gene was cloned into a chloroplast vector and transformed into tobacco using the biolistic method. In order to first determine whether codon modification would result in enhanced expression of the bacterial tetC gene in the plastid, the researchers transformed tobacco plants with two different gene constructs: a native AT-rich bacterial gene (tetC-AT) and a codon-optimized synthetic GC-rich gene (tet $C$-GC). Transplastomic tobacco plants showed chloroplast TetC protein accumulation up to $25 \%$ and $10 \%$ of total soluble proteins for the native and synthetic genes, respectively. The results revealed that codon optimization, in this particular case, did not necessarily translate into higher protein expression. This was probably due to the fact that, although eukaryotes, plants plastids have features that are similar to prokaryotic machinery for gene transcription and translation.

To test the immunogenic properties of the recombinant TetC protein, Tregoning et al. (2003) inoculated mice with leaf extracts from transgenic tobacco expressing the tetC gene. Mice immunized with the transgenic leaf extracts showed significant anti-TetC antibody responses and survived when challenged with $C$. tetani, while control mice immunized with wild-type leaf extracts did not give any antibody response and showed symptoms of paralysis 42 hrs after infection with $C$. tetani. These results showed that plants could be successfully used to produce high levels of active subunit proteins that can be used to fight tetanus infection.

\section{Escherichia coli}

Enterotoxigenic Escherichia coli causes a disease called gastroenteritis, which is marked by mild diarrhoea and vomiting. Gastroenteritis is triggered by the release of heatlabile enterotoxin (LT) produced by the enterotoxigenic $E$. coli. LT is formed by a toxic $27-\mathrm{kDa}$ A subunit (LTA) and a non toxic $11.6 \mathrm{kDa} \mathrm{B}$ subunit (LTB). It has been shown previously that animals feeding on transgenic plants expressing LTB produced antibodies that could neutralize LT, however, LTB expression in plants were too low (Mason et al. 1998). In order to increase LTB expression,
Kang et al. (2003) used biolistic methods to transfer the ltb gene into tobacco chloroplast. The researchers observed that in transplastomic tobacco leaf the LTB protein was approximately $2.5 \%$ of the total soluble protein, which is approximately 250 -fold higher than in plants generated via nuclear transformation in previous research.

Bloody diarrhea or hemorrhagic colitis is caused by the enterohemorrhagic E. coli O157:H7. These bacteria are typically transmitted from infected cattle to humans; therefore, vaccination of cattle in order to decrease levels of E. coli $\mathrm{O} 157: \mathrm{H} 7$ could lead to a reduction of hemorrhagic colitis infection in humans (Zhao et al. 1998). Previous studies have shown that the $E$. coli outer membrane protein intimin is effective in eliciting immunogenic responses in cattle and pigs (Gansheroff et al. 1999). Judge et al. (2004) transformed tobacco with the E. coli intimin (eae) gene, fused to the signal sequence from the soybean vegetative storage protein (VspA), using Agrobacterium. The transgenic plants produced up to $13 \mu \mathrm{g}$ of intimin per $\mathrm{g}$ of total plant material. Purified intimin from transgenic tobacco induced immune response in mice. When challenged with E. coli $\mathrm{O} 157: \mathrm{H7}$, mice that were injected with intimin and fed with transgenic plant tissue showed significant decrease in duration of $E$. coli colonization in the gut.

\section{Vibrio cholerae}

Vibrio cholerae is a Gram-negative bacterium that affects the small intestine of humans and causes the disease cholera. Once it colonizes the intestinal epithelial cells, $V$. cholerae produces large amounts of cholera toxin (CT), which is responsible for the symptoms associated with the cholera disease. Similar to the heat-labile $E$. coli enterotoxin (LT), the CT is composed of two subunits: a toxic $27-\mathrm{kDa}$ A subunit (CTA) and a non toxic 11.6-kDa B subunit (CTB). CTB is a candidate oral subunit vaccine for cholera because it has strong mucosal immunogenic properties (Jani et al. 2004). Daniell et al. (2001) used biolistic transformation method to integrate the $c t b$ gene into the tobacco chloroplast genome. The resulting transgenic plants showed CTB expression up to $4.1 \%$ of total soluble protein. The binding of CTB to the GM1 ganglioside receptors on the surface of intestinal epithelial cells is believed to elicit the mucosal immune response to $V$. cholerae infection. The plant-synthesized recombinant CTB showed strong affinity to the GM1 receptors on the surface of intestinal epithelial cells.

\section{PLANT MOLECULAR FARMING}

Molecular farming, which is the use of transgenic plants for large-scale production of valuable compounds such as industrial enzymes, food additives, and biopolymers, is preferred over more traditional production systems using 
animal or microbial cells because it enables mass production at low cost. Scientists have introduced bacterial genes in transgenic tobacco plants for the production of valuable compounds including sweeteners (mannitol), polymers (biodegradable plastic), and enzymes (cellulase and $\alpha$-amylase).

\section{Mannitol}

Mannitolis one of several carbohydrates classified as a sugar alcohol. The main commercial use of mannitol is in the food industry, in which it is used as a nutritive sweetener. Mannitol is an important food sweetener because it slowly degrades in the body, it has low caloric content, and it is resistant to tooth decaying bacteria. To develop an efficient and inexpensive method for mannitol production, Tarczynski et al. (1992) introduced into tobacco plants the E. coli mtlD gene, which encodes the enzyme mannitol-1-phosphate dehydrogenase. Transgenic plants were developed using Agrobacterium-mediated gene transfer. Transgenic plants expressing $m t l D$ showed mannitol concentrations up to $6 \mu \mathrm{mol} / \mathrm{g}$ of fresh weight, while mannitol accumulation could not be detected inuntransformed tobacco. This experiment demonstrates that it is possible to alter plant carbohydrate metabolism through gene manipulation, in order to produce commercially valuable compounds.

\section{Polyhydroxybutyrate}

Polyhydroxyalkanoates (PHAs) are a class of linear polyesters naturally produced by bacteria through fermentation of sugar or lipids. The most common type of PHAs is polyhydroxybutyrate (PHB), which has attracted much commercial interest as a biodegradable plastic material. Recombinant bacteria were originally used to produce $\mathrm{PHB}$, but production costs were too high compared to production of synthetic plastics (Choi and Lee, 1999). As an alternative, researchers have attempted to produce PHB in transgenic plants including Arabidopsis thaliana (Poirier et al. 1992; Bohmert et al. 2000), Brassica napus (Houmiel et al. 1999), corn (Poirier and Gruys, 2002), potato (Bohmert et al. 2002), sugarcane (Petrasovits et al. 2007; Purnell et al. 2007), and tobacco (Bohmert et al. 2002; Lössl et al. 2003; Arai et al. 2004).

PHB is biosynthesized by bacteria using the substrate acetyl-CoA through the action of three enzymes encoded by $p h b A$ ( $\beta$-ketothiolase), $p h b B$ (acetoacetyl-CoA reductase), and $p h b C$ (PHB synthase). $\beta$-ketothiolase converts acetylCoA to acetoacetyl-CoA, which is reduced by acetoacetylCoA reductase to 3-hydroxybutyryl-CoA, and then polymerized by PHB synthase to produce PHB. In transgenic plants, all three genes are required to synthesize PHB in plastids, but only $p h b C$ and $p h b B$ are needed for PHB production in cytosol (Poirier et al. 1992). However, constitutive expression of $\beta$-ketothiolase can be deleterious during transgenic plant regeneration.

To curb the negative effects of $\beta$-ketothiolase in plant transformation, Bohmert et al. (2002) placed the somatically activated maize transposable Activator element (Ac) between the 35S CaMV promoter and the $p h b A$ gene from Ralstonia eutropha, allowing expression of $\beta$ ketothiolase only after the mobile Ac element has been removed. Ac is known to transpose autonomously at high frequency to new sites in the tobacco genome, leading to fusion of the $35 \mathrm{~S} \mathrm{CaMV}$ promoter to the target gene (Hehl and Baker, 1990). Through Agrobacterium-mediated transformation, the researchers produced transgenic tobacco plants that showed PHB accumulation up to $3.2 \mathrm{mg} / \mathrm{g}$ of dry weight. In another research aiming for the production of PHB in transgenic tobacco, Lössl et al. (2003) transferred the polycistronic phb operonto tobacco plastome using biolistic transformation methods. The researchers observed that the highest PHB accumulation (1.7\% dry weight) was achieved only during the early stages of in vitro culture. PHB production in transplastomic tobacco plants decreased over time and mature plants showed stunted growth and male sterility. While these expression levels are still not ideal for large-scale commercial production of PHB, these experiments laid the foundation toward achieving this goal.

\section{Cellulase}

Cellulose, a long chain polysaccharide made up of repeating units of $\beta$-D-glucose, is the major component of woody plants and natural fibers and considered one of the most abundant organic materials. Besides the traditional use of cellulose as raw material in the manufacturing of products such as paper and textile, cellulose can also be used for ethanol production. Commercial production of the enzyme cellulase, used for cellulose hydrolysis during ethanol production, has been derived mainly from the fungus Trichoderma reesei. To reduce the cost of cellulase production, Jin et al. (2003) used Agrobacterium-mediated transformation to introduce into tobacco plants a gene $(e 1)$ encoding the catalytic domain of a thermotolerant cellulase endo-1,4- $\beta$-D-glucanase (E1) from Acidothermus cellulolyticus, fused to a transit sequence and the $35 \mathrm{~S}$ CaMV promoter. The transgenic tobacco plants showed high levels of endoglucanase activity, suggesting that transgenic plants can be used for commercial production of cellulase.

\section{a-amylase}

Amylases are a family of enzymes that hydrolyze the bond within starch molecules to produce glucose. $\alpha$-amylases hydrolyses 1,4- $\alpha$-glycosidic linkages in the amylose and amylopectin molecules of starch and are extensively used in a variety of industries including starch, food, brewing, alcohol, sugar, textile, and paper industries. Pen et al. (1992) expressed the thermostable $\alpha$-amylase, isolated from 
Bacillus licheniformis in transgenic tobacco plants. Tobacco protoplasts were transformed with a construct containing a fusion between the $B$. licheniformis $\alpha$-amylase gene, amyl, and the signal peptide of the tobacco PR-S protein, which targets the protein to the apoplast. The resultant transgenic tobacco plants showed normal phenotype and secreted $\alpha$-amylase into the intercellular space, with expression levels up to $0.3 \%$ of total soluble proteins. The activity of plant-expressed recombinant $\alpha$ amylase was tested by applying extracts of transgenic seeds directly in the hydrolysis of starch, which resulted in liquefied products that were similar to those obtained from starch hydrolysis using wild-type $\alpha$-amylase from $B$. licheniformis. Although expression levels obtained from this research were too low for effective large-scale production of $\alpha$-amylase, this study demonstrated the expression of a commercially important industrial enzyme in transgenic plants. Future studies will be needed to increase expression levels for viable commercial application.

\section{FUTURE PROSPECTS}

Recent advances in genomics, proteomics and bioinformatics have allowed the identification of many bacterial and plant genes involved in a variety of biological functions such as tolerance to abiotic stresses, pathogen/insect/herbicide resistance, biodegradation of xenobiotics, and biosynthesis of vaccines, pharmaceuticals, and other industrial compounds. Greater functional determination of different genes will provide a better understanding of the biochemical and physiological processes in plants and bacteria, which in turn will enhance the expression of recombinant bacterial genes in plants. With the information derived from tobacco, it should become possible to manipulate metabolic pathways and optimize protein expression levels for the improvement of crops and for large-scale production of desirable proteins. Further developments in the area of gene expression and protein purification methods will be necessary for commercial use of plants as bioreactors.

One of the biggest obstacles for the successful commercial use of transgenic plants in the production of industrial grade recombinant proteins is to extract these proteins in an efficient and inexpensive manner. Expression levels of recombinant proteins in plants are increasing steadily with advances in plastid-targeted transformation methods, which allow transfer of multiple genes at the same time. However, extraction and purification of proteins from transgenic plants are still labour-intensive and costly. The use of callus and hairy roots cell cultures, root secretion, and guttation fluid extraction systems are some alternative methods for the recovery of valuable proteins from transgenic plants that may be simpler and more costefficient than currently used methods.
There are many advantages associated with the use of whole plants for the production of recombinant proteins compared with traditional microbial and mammalian recombinant protein production systems. However, production systems that use whole plants lack several benefits found in cultured cells, including containment, growth conditions control, product consistency, and the ability to produce recombinant proteins in compliance with standard manufacturing regulations. Plant cell cultures combine both the qualities of whole-plant systems and of microbial and animal cell cultures. Even though the commercial production of recombinant proteins using plant cell cultures has not yet been realized, many studies have been conducted in order to evaluate the commercial viability of such systems.

The constant need for more abundant and improved food sources can be met by the applications of biotechnology in the production of bioengineered plants that are more nutritious, productive, and that require less pesticides and fertilizers. Nevertheless, there has been a greater awareness on the potential negative impact of bioengineered plants on non-target organisms and the environment as a whole. Only few actual studies have been conducted with bioengineered plants grown in the wild. Hence, there is a real need for the establishment of more long-term research to address these issues. The scientific community has established rules and guidelines to help decrease the chances of transgene pollution in the environment, minimizing the possible adverse effects of bioengineered plants. Some of these guidelines include localizing the expression of exogenous genes only to specific tissues and organs; limiting their expression to the time when foreign proteins are needed; excluding all excess foreign DNA, such as selective markers, from transgenic plants; and minimizing the risk of gene flow to other plants via cross-pollination. The probability of exogenous genes escape can be decreased by methods that remove these genes from pollen. One of these methods is the insertion of the transgene into the chloroplast (plastid) rather than the nucleus. Since chloroplast genes are inherited maternally, the transgene will not be present in the pollen, avoiding its unwanted dispersal.

Besides limiting the escape of the foreign gene into the environment, plastid transformation system has many other advantages over nuclear transformation, which is still the most common method for generating transgenic plants. Plastids have some prokaryotic features, such as the organization of genes in operons, which enhance levels of expression of native bacterial genes. Since transgenes are inserted into the plastid by homologous recombination, their expression is more stable and predictable than in nuclear transformed plants. In nuclear transformants, lower expression levels and gene silencing may occur due to the unpredictable insertion of the foreign gene in the 
chromosome, causing what is know as 'position effect'. Chloroplast transformation allows the insertion of several transgenes under the control of a single promoter, enabling the coordinated expression of the genes. Also, there are approximately 10,000 copies of the plastid genome in each plant cell, which enhance considerably the expression of recombinant proteins in transplastomic plants. The advantages of chloroplast-targeted expression of bacterial genes in plants have been demonstrated well in transgenic tobacco using $B$. thuringiensis cry genes, as described above.

\section{REFERENCES}

ARAI, Yuko; SHIKANAI, Toshiharu; DOI, Yoshiharu; YOSHIDA, Shigeo; YAMAGUCHI, Isamu and NAKASHITA, Hideo. Production of polyhydroxybutyrate by polycistronic expression of bacterial genes in tobacco plastid. Plant and Cell Physiology, September 2004, vol. 45, no. 9, p. 1176-1184.

ARLAT, M.; VAN GIJSEGEM, F.; HUET, J.C.; PERNOLLET, J.C. and BOUCHER, C.A. PopA1, a protein which induces a hypersensitivity-like response on specific Petunia genotypes, is secreted via the Hrp pathway of Pseudomonas solanacearum. European Molecular Biology Organization Journal, February 1994, vol. 13, no. 3, p. 543-553.

BELBAHRI, Lassaad; BOUCHER, Christian; CANDRESSE, Thierry; NICOLE, Michel; RICCI, Pierre and KELLER, Harald. A local accumulation of the Ralstonia solanacearum PopA protein in transgenic tobacco renders a compatible plant-pathogen interaction incompatible. The Plant Journal, November 2001, vol. 28, no. 4 , p. 419-430.

BINKS, Peter R.; FRENCH, Christopher E.; NICKLIN, Stephen and BRUCE, Neil C. Degradation of pentaerythritol tetranitrate by Enterobacter cloacae PB2. Applied and Environmental Microbiology, April 1996, vol. 62 , no. 4, p. 1214-1219.

BOHMERT, Karen; BALBO, Ilse; KOPKA, Joachim; MITTENDORF, Volker; NAWRATH, Christiane; POIRIER, Yves; TISCHENDORF, Gilbert; TRETHEWEY, Richard N. and WILLMITZER, Lothar. Transgenic Arabidopsis plants can accumulate polyhydroxybutyrate to up to $4 \%$ of their fresh weight. Planta, November 2000, vol. 211, no. 6, p. 841-845.

BOHMERT, Karen; BALBO, Ilse; STEINBUCHEL, Alexander; TISCHENDORF, Gilbert and WILLMITZER, Lothar. Constitutive expression of the $\beta$-ketothiolase gene in transgenic plants. A major obstacle for obtaining polyhydroxybutyrate-producing plants. Plant Physiology, April 2002, vol. 128, no. 4, p. 1282-1290.
CHOI, Jong-Il and LEE, Sang Yup. Factors affecting the economics of polyhydroxyalkanoate production bacterial fermentation. Applied Microbiology and Biotechnology, January 1999, vol. 51, no. 1, p. 13-21.

CORBIN, David R.; GREENPLATE, John T.; WONG, Edith Y. and PURCELL, John P. Cloning of an insecticidal cholesterol oxidase gene and its expression in bacteria and plant protoplasts. Applied and Environmental Microbiology, December 1994, vol. 60, no. 12, p. 42394244.

CORBIN, David R.; GREBENOK, Robert J.; OHNMEISS, Thomas E.; GREENPLATE, John T. and PURCELL, John P. Expression and chloroplast targeting of cholesterol oxidase in transgenic tobacco plants. Plant Physiology, July 2001, vol. 126, no. 3, p. 1116-1128.

DANIELL, Henry; LEE, Seung-Burn; PANCHAL, Tanvi and WIEBE, Peter O. Expression of the native Cholera Toxin $B$ subunit gene and assembly as functional oligomers in transgenic tobacco chloroplasts. Journal of Molecular Biology, August 2001, vol. 311, no. 5, p. 1001-1009.

DONG, Yi-Hu; WANG, Lian-Hui; XU, Jin-Ling; ZHANG, Hai-Bao; ZHANG, Xi-Fen and ZHANG, Lian-Hui. Quenching quorum-sensing dependent bacterial infection by an $N$-acyl homoserine lactonase. Nature, June 2001, vol. 411, no. 6839, p. 813-817.

FRENCH, Christopher E.; NICKLIN, Stephen and BRUCE, Neil C. Aerobic degradation of 2,4,6trinitrotoluene by Enterobacter cloacae PB2 and by pentaerythritol tetranitrate reductase. Applied and Environmental Microbiology, August 1998, vol. 64, no. 8, p. 2864-2868.

FRENCH, Christopher E.; ROSSER, Susan J.; DAVIES, George J.; NICKLIN, Stephen and BRUCE, Neil C. Biodegradation of explosives by transgenic plants expressing pentaerythritol tetranitrate reductase. Nature Biotechnology, May 1999, vol. 17, no. 5, p. 491-494.

GANSHEROFF, Lisa J.; WACHTEL, Marian R. and O'BRIEN, Alison D. Decrease adherence of enterohemorrhagic Escherichia coli to HEp-2 cells in the presence of antibodies that recognize the C-terminal region of intimin. Infection and Immunity, December 1999, vol. 67 , no. 12 , p. 6409-6417.

GÖTZ, Thomas; SANDMANN, Gerhard and RÖMER, Susanne. Expression of a bacterial carotene hydrolase gene (crtZ) enhances UV tolerance in tobacco. Plant Molecular Biology, September 2002, vol. 50, no. 1, p. 129-142. 
HANNINK, Nerissa; ROSSER, Susan J.; FRENCH, Christopher E.; BASRAN, Amrik; MURRAY, James A.H.; NICKLIN, Stephen and BRUCE, Neil C. Phytodetoxification of TNT by transgenic plants expressing a bacterial nitroreductase. Nature Biotechnology, December 2001, vol. 19, no. 12, p. 1168-1172.

HATZILOUKAS, Efstathios and PANOPOULOS, Nickolas J. Origin, structure, and regulation of $\arg K$, encoding the phaseolotoxin-resistant ornithine carbamoyltransferase in Pseudomonas syringae pv. phaseolicola, and functional expression of $\arg K$ in transgenic tobacco. Journal of Bacteriology, September 1992, vol. 174, no. 18 , p. 5895-5909.

HE, Ming; YANG, Zhong-Yi; Nie, Yan-Fang; WANG, Jun and XU, Peilin. A new type of class I bacterial 5enopyruvylshikimate-3-phosphate synthase mutants with enhanced tolerance to glyphosate. Biochimica et Biophysica Acta, November 2001, vol. 1568, no. 1, p. 1-6.

HE, Yu Ke; SUN, Jian Ge; FENG, Xian Zhong; CZAKO, Mihaly and MARTON, László. Differential mercury volatilization by tobacco organs expressing a modified bacterial merA gene. Cell Research, September 2001, vol. 11, no. 3, p. 231-236.

HEHL, Reinhard and BAKER, Barbara. Properties of the maize transposable element Activator in transgenic tobacco plants: a versatile inter-species genetic tool. Plant Cell, August 1990, vol. 2, no. 8, p. 709-721.

HOLMSTRÖM, Kjell-Ove; SOMERSALO, Susanne; MANDAL, Abul; PALVA, Tapio E. and WELIN, Björn. Improved tolerance to salinity and low temperature in transgenic tobacco producing glycine betaine. Journal of Experimental Botany, February 2000, vol. 51, no. 343, p. 177-185.

HOUMIEL, Kathryn L.; SLATER, Steven; BROYLES, Debra; CASAGRANDE, Laura; COLBURN, Susan; GONZALEZ, Kathleen; MITSKY, Timothy A.; REISER, Steven E.; SHAH, Devang; TAYLOR, Nancy B.; TRAN, Mintien; VALENTIN, Henry E. and GRUYS, Kenneth J. Poly( $\beta$-hydroxybutyrate) production in oilseed leukoplasts of Brassica napus. Planta, October 1999, vol. 209, no. 4, p. 547-550.

HUANG, Jun; HIRJI, Rozina; ADAM, Luc; ROZWADOWSKI, Kevin L.; HAMMERLINDL, Joe K.; KELLER, Wilf A. and SELVARAJ, Gopalan. Genetic engineering of glycinebetaine production toward enhancing stress tolerance in plants: metabolic limitations. Plant Physiology, March 2000, vol. 122, no. 3, p. 747-756.

JANI， D.; SINGH， N.K.; BHATTACHARYA， S.; MEENA, L.S.; SINGH, Y.; UPADHYAY, S.N.;
SHARMA, A.K. and TYAGI, A.K. Studies on the immunogenic potential of plant-expressed cholera toxin B subunit. Plant Cell Reports, February 2004, vol. 22, no. 7, p. $471-477$.

JANSEN, Marcel A.K.; GABA, Victor and GREENBERG, Bruce M. Higher plants and UV-B radiation: balancing damage, repair and acclimation. Trends in Plant Science, April 1998, vol. 3, no. 4, p. 131-135.

JIN, Rongguan; RICHTER, Stefan; ZHONG, Rong and LAMPPA, Gayle K. Expression and import of an active cellulase from a thermophilic bacterium into the chloroplast both in vitro and in vivo. Plant Molecular Biology, March 2003, vol. 51, no. 4, p. 493-507.

JO, Jinki; WON, Sung-Hye; SON, Daeyoung and LEE, Byung-Hyun. Paraquat resistance of transgenic tobacco plants over-expressing the Ochrobactrum anthropipqrA gene. Biotechnology Letters, September 2004, vol. 26, no. 18, p. 1391-1396.

JUDGE, Nicole A.; MASON, Hugh S. and O'BRIEN, Allison D. Plant cell-based intimin vaccine given orally to mice primed with intimin reduces time of Escherichia coli O157:H7 shedding in feces. Infection and Immunity, January 2004, vol. 72, no. 1, p. 168-175.

KANG, Tae-Jin; LOC, Nguyen-Hoang; JANG, Mi-Ok; JANG, Yong-Suk; KIM, Young-Sook; SEO, Jo-Eun and YANG, Moon-Sik. Expression of the B subunit of E. coli heat-labile enterotoxin in the chloroplasts of plants and its characterization. Transgenic Research, December 2003, vol. 12 , no. 6 , p. 683-691.

KOTA, Madhuri; DANIELL, Henry; VARMA, Sam; GARCZYNSKI, Stephen F.; GOULD, Fred and MOAR, William J. Overexpression of the Bacillus thuringiensis (Bt) Cry2Aa2 protein in chloroplasts confers resistance to plants against susceptible and Bt-resistant insects. Proceedings of the National Academy of Sciences of the United States of America, March 1999, vol. 96, no. 5, p. 1840-1845.

LANDFALD, Bjarne and STRØM, Arne R. Cholineglycine betaine pathway confers a high level of osmotic tolerance in Escherichia coli. Journal of Bacteriology, March 1986, vol. 165, no. 3, p. 849-855.

LOS, Dmitry A. and MURATA, Norio. Structure and expression of fatty acid desaturases. Biochimica et Biophysica Acta - Lipids and Lipid Metabolism, October 1998, vol. 1394, no. 1, p. 3-15.

LÖSSL, A.; EIBL, C.; HARLOFF, H.-J.; JUNG, C. and KOOP, H.-U. Polyester synthesis in transplastomic tobacco (Nicotiana tabacum L.): significant contents of polyhydroxybutyrate are associated with growth reduction. Plant Cell Reports, June 2003, vol. 21, no. 9, p. 891-899. 
LUTZ, Kerry A.; KNAPP, Jane E. and MALIGA, Pal. Expression of bar in the plastid genome confers herbicide resistance. Plant Physiology, April 2001, vol. 125, no. 4, p. 1585-1590.

LYON, Bruce R.; LLEWELLYN, Danny J.; HUPPATZ, John L.; DENNIS, Elizabeth S. and PEACOCK, W. James. Expression of a bacterial gene in transgenic tobacco plants confers resistance to the herbicide 2,4dichlorophenoxyacetic acid. Plant Molecular Biology, November 1989, vol. 13, no. 5, p. 533-540.

MAE, Andres; MONTESANO, Marcos; KOIV, Viia and PALVA, E. Tapio. Transgenic plants producing the bacterial pheromone $N$-acyl-homoserine lactone exhibit enhanced resistance to the bacterial phytopathogen Erwinia carotovora. Molecular Plant-Microbe Interaction, September 2001, vol. 14, no. 9, p. 1035-1042.

MASON, Hugh S.; HAQ, Tariq A.; CLEMENTS, John D. and ARNTZEN, Charles J. Edible vaccine protects mice against Escherichia coli heat-labile enterotoxin (LT): potatoes expressing a synthetic LT-B gene. Vaccine, August 1998, vol. 16, no. 13, p. 1336-1343.

METRAUX, J.P.; SIGNER, H.; RYALS, J.; WARD, E.; WYSS-BENZ, M.; GAUDIN, J.; RASCHDORF, K.; SCHMID, E.; BLUM, W. and INVERARDI, B. Increase in salicylic acid at the onset of systemic acquired resistance in cucumber. Science, November 1990, vol. 250, no. 4983, p. 1004-1006.

MITTLER, Ron; SHULAEV, Vladimir and LAM, Eric. Coordinated activation of programmed cell death and defense mechanisms in transgenic tobacco plants expressing a bacterial proton pump. Plant Cell, January1995, vol. 7, no. 1, p. 29-42.

MOSQUEDA, Gilberto; VAN DEN BROEK, Guido; SAUCEDO, Odila; BAILEY, Ana Maria; ALVAREZMORALES, Ariel and HERRERA-ESTRELLA, Luis. Isolation and characterization of a gene from Pseudomonas syringae pv. phaseolicola encoding a phaseolotoxininsensitive ornithine carbamoyltransferase. Molecular and General Genetics, July 1990, vol. 222, no. 2-3, p. 461-466.

MURATA, Norio and LOS, Dmitry A. Membrane fluidity and temperature perception. Plant Physiology, November 1997, vol. 115 , no. 3 , p. 875-879.

NISHIDA, I. and MURATA, N. Chilling sensitivity in plants and cyanobacteria: the crucial contribution of membrane lipids. Annual Review of Plant Physiology and Plant Molecular Biology, June 1996, vol. 47, p. 541-568.
NIYOGI, Krishna K. Photoprotection revisited: genetic and molecular approaches. Annual Review of Plant Physiology and Plant Molecular Biology, June 1999, vol. 50, p. 333 359.

ORLOVA, Irina V.; SEREBRIISKAYA, Tatiana; POPOV, Valeri; MERKULOVA, Natalia; NOSOV, Alexander M.; TRUNOVA, Tamara I.; TSYDENDAMBAEV, Vladimir D. and LOS, Dmitry A. Transformation of tobacco with a gene for the thermophilic acyl-lipid desaturase enhances the chilling tolerance of plants. Plant and Cell Physiology, April 2003, vol. 44, no. 4, p. 447-450.

PASCUAL, F. Brian; MC GINLEY, Emily L.; ZANARDI, Lynn R.; CORTESE, Margaret M. and MURPHY, Trudy V. Tetanus surveillance - United States, 1998-2000. Morbidity and Mortality Weekly Report, June 2003, vol. 52, no. SS-3, p. 1-12.

PEN, Jan; MOLENDIJK, Lucy; QUAX, Wim J.; SIJMONS, Peter C.; VAN OOYEN, Albert J.J.; VAN DE ELZEN, Peter J.M.; RIETVELD, Krijn and HOEKEMA, Andre. Production of active Bacillus licheniformis $\alpha$ amylase in tobacco and its application in starch liquefaction. Biotechnology, March 1992, vol. 10, no. 3, p. 292-296.

PETRASOVITS, Lars A.; PURNELL, Matthew P.; NIELSEN, Lars $\mathrm{K}$. and BRUMBLEY, Stevens $M$. Production of polyhydroxybutyrate in sugarcane. Plant Biotechnology Journal, January 2007, vol. 5, no. 1, p. 162172.

PIRHONEN, Minna; FLEGO, Diana; HEIKINHEIMO, Riikka and PALVA, E. Tapio. A small diffusible signal molecule is responsible for the global control of virulence and exoenzyme production in the plant pathogen Erwinia carotovora. European Molecular Biology Organization Journal, June 1993, vol. 12, no. 6, p. 2467-2476.

PITTMAN, Phillip R. Aluminum-containing vaccine associated adverse events: role of route of administration and gender. Vaccine, May 2002, vol. 20, suppl. 3, p. S48S50.

POGUE, Gregory P.; LINDBO, John A.; GARGER, Stephen J. and FITZMAURICE, Wayne P. Making an ally from an enemy: plant virology and the new agriculture. Annual Review of Phytopathology, September 2002, vol. 40, p. 45-74.

POHLENZ, Hans-Dieter; BOIDOL, Werner; SCHÜTTKE, Iris and STREBER, Wolfgang R. Purification and properties of an Arthrobacter oxydans P52 carbamate hydrolase specific for the herbicide phenmedipham and 
nucleotide sequence of the corresponding gene. Journal of Bacteriology, October 1992, vol. 174, no. 20, p. 6600-6607.

POIRIER, Yves; DENNIS, Douglas E.; KLOMPARENS, Karen and SOMERVILLE, Chris. Polyhydroxybutyrate, a biodegradable thermoplastic, produced in transgenic plants. Science, April 1992, vol. 256, no. 5056, p. 520-523.

POIRIER, Y. and GRUYS, K.J. Production of polyhydroxyalkanoates in transgenic plants. In: STEINBÜCHEL, Alexander ed. Biopolymers. Wiley-Vch Verlag Gmbh, Weinheim, Denmark, 2002, p. 401-435.

PURNELL, Matthew P.; PETRASOVITS, Lars A.; NIELSEN, Lars K. and BRUMBLEY, Stevens M. Spatiotemporal characterisation of polyhydroxybutyrate accumulation in sugarcane. Plant Biotechnology Journal, January 2007, vol. 5, no. 1, p. 173-184.

RIZHSKY, Ludmila and MITTLER, Ron. Inducible expression of bacterio-opsin in transgenic tobacco and tomato plants. Plant Molecular Biology, June 2001, vol. 46, no. 3, p. 313-323.

ROBINSON, S.P. and JONES, G.P. Accumulation of glycine betaine in chloroplasts provides osmotic adjustment during salt stress. Australian Journal of Plant Physiology, 1986, vol. 13 , no. 5 , p. 659-668.

SMIGOCKI, A.; NEAL, J.W. Jr.; MC CANNA, I. and DOUGLASS, L. Cytokinin-mediated insect resistance in Nicotiana plants transformed with the ipt gene. Plant Molecular Biology, October 1993, vol. 23, no. 2, p. 325235.

STREBER, Wolfgang R.; TIMMIS, Kenneth N. and ZENK, Meinhart H. Analysis, cloning, and high-level expression of 2,4-dichlorophenoxyacetate monooxygenase gene tfdA of Alcaligenes eutrophus JMP134. Journal of Bacteriology, July 1987, vol. 169, no. 7, p. 2950-2955.

STREBER, Wolfgang R.; KUTSCHKA, Ulrike; THOMAS, Frank and POHLENZ, Hans-Dieter. Expression of a bacterial gene in transgenic plants confers resistance to the herbicide phenmedipham. Plant Molecular Biology, September 1994, vol. 25, no. 6, p. 977-987.

SUMMERS, Anne O. Organization, expression and evolution of genes for mercury resistance. Annual Review of Microbiology, October 1986, vol. 40, p. 607-634.

TARCZYNSKI, Mitchell C.; JENSEN, Richard G. and BOHNERT, Hans J. Expression of a bacterial $m t l D$ gene in transgenic tobacco leads to production and accumulation of mannitol. Proceedings of the National Academy of Sciences of the United States of America, April 1992, vol. 89, no. 7, p. $2600-2604$.
TEMPLETON, Matthew D.; REINHARDT, Laurie A.; COLLYER, Charles A.; MITCHELL, Robin E. and CLELAND, W. Wallace. Kinetic analysis of the Lornithine transcarbamoylase from Pseudomonas savastanoi pv. phaseolicola that is resistant to the transition state analogue (R)-N delta-(N'-sulfodiaminophosphinyl)-Lornithine. Biochemistry, March 2005, vol. 44, no. 11, p. 4408-4415.

THOMPSON, Charles J.; MOVVA, N. Rao; TIZARD, Richard; CRAMERI, Reto; DAVIES, Julian E.; LAUWEREYS, Marc and BOTTERMAN, Johan. Characterization of the herbicide-resistance gene bar from Streptomyces hygroscopicus. European Molecular Biology Organization Journal, September 1987, vol. 6, no. 9, p. 2519-2523.

TREGONING, John S.; NIXON, Peter; KURODA, Hiroshi; SVAB, Zora; CLARE, Simon; BOWE, Frances; FAIRWEATHER, Neil; YTTERBERG, Jimmy; VAN WIJK, Klass J.; DOUGAN, Gordon and MALIGA, Pal. Expression of tetanus toxin Fragment $\mathrm{C}$ in tobacco chloroplasts. Nucleic Acids Research, February 2003, vol. 31, no. 4, p. 1174-1179.

VERBERNE, Marianne C.; VERPOORTE, Rob; BOL, John F.; MERCADO-BLANCO, Jesus and LINTHORST, Huub J.M. Overproduction of salicylic acid in plants by bacterial transgenes enhances pathogen resistance. Nature Biotechnology, July 2000, vol. 18, no. 7, p. 779-783.

VON BODMAN, Susanne B.; BAUER, W. Dietz and COPLIN, David L. Quorum sensing in plant-pathogenic bacteria. Annual Review of Phytopathology, September 2003, vol. 41, p. 455-482.

WANG, He-Yong; LI, Yun-Feng; XIE, Long-Xu and XU, Peilin. Expression of a bacterial aroA mutant, aroA-M1, encoding 5-enolpyruvylshikimate-3-phosphate synthase for the production of glyphosate-resistant tobacco plants. Journal of Plant Research, December 2003, vol. 116, no. 6, p. $455-460$.

WATSON, Jennifer; KOYA, Vijav; LEPPLA, Stephen H. and DANIELL, Henry. Expression of Bacillus anthracis protective antigen in transgenic chloroplasts of tobacco, a non-food/feed crop. Vaccine, October 2004, vol. 22, no. 3132, p. 4374-4384.

WILD, A. and WENDLER, C. Effect of glufosinate (phosphinothricin) on amino acid content, photorespiration, and photosynthesis. Pesticide Science, 1991, vol. 30, p. 422-424.

WON, Sung-Hye; LEE, Byung-Hyun; LEE, Hyo-Shin and JO, Jinki. An Ochrobactrum anthropi gene conferring 
Jube, S. and Borthakur, D.

paraquat resistance to the heterologous host Escherichia coli. Biochemical and Biophysical Research Communications, July 2001, vol. 285, no. 4, p. 885-890.

ZHAO, Tong; DOYLE, Michael P.; HARMON, Barry G.; BROWN, Cathy A.; MUELLER, Eric P.O. and PARKS, Andrew H. Reduction of carriage of enterohemorrhagic Escherichia coli $\mathrm{O} 157: \mathrm{H} 7$ in cattle by inoculation with probiotic bacteria. Journal of Clinical Microbiology, March 1998, vol. 36, no. 3, p. 641-647.

ZHOU, H.; BERG, J.D.; BLANK, S.E.; CHAY, C.A.; CHEN, G.; ESKELSEN, S.R.; FRY, J.E.; HOI, S.; HU, T.; ISAKSON, P.J.; LAWTON, M.B.; METZ, S.G.; REMPEL, C.B.; RYERSON, D.K.; SANSONE, A.P.; SHOOK, A.L.; STARKE, R.J.; TICHOTA, J.M. and VALENTI, S.A. Field efficacy assessment of transgenic Roundup ready wheat crop. Crop Science, May-June 2003, vol. 43, no. 3, p. 10721075. 